\title{
PERFORMANCE OF HYBRID MAIZE VARIETIES AS INFLUENCED BY IRRIGATION LEVELS
}

\author{
M. S. Bhuiyan ${ }^{1}$, M. S. R. Bhuiyan ${ }^{2}$, T. P. Tiwari $^{3}$, M. A. Rahaman ${ }^{4}$ S. K. Bhowal ${ }^{5}$, \\ R. Uddin ${ }^{6}$ and S. K. Paul ${ }^{1}$ \\ ${ }^{1}$ Agronomy Division, BARI, Gazipur, Bangladesh \\ ${ }^{2}$ Department of Genetics and Plant Breeding, SAU, Dhaka, Bangladesh \\ ${ }^{3}$ CIMMYT-Bangladesh, Dhaka, Bangladesh \\ ${ }^{4}$ OFRD, BARI, Tangail, Bangladesh; ${ }^{5}$ OFRD, BARI, Comilla, Bangladesh \\ ${ }^{6}$ RARS, BARI, Barisal, Bangladesh \\ Corresponding author's: sawkatsarfuddin@gmail.com
}

Key words: Hybrid maize, Irrigation levels, Water Saving

\begin{abstract}
The present piece of research work was carried out at the field of Sher-e-Bangla Agricultural University, Dhaka-1207, from December 2010 to May 2011 to determine optimum irrigation levels for the hybrid maize varieties. There were four hybrid maize varieties: $V_{1}$ (BARI Hybrid Maize-5), $V_{2}$ (Pacific 60), $V_{3}$ (NK 40) and $V_{4}$ (Ajanta) and three levels of irrigation: $l_{1}=$ Two irrigations at 25 and 50 DAS, $l_{2}=$ Three irrigations at 25, 50 and 75 DAS and $I_{3}=$ Four irrigations at 25, 50, 75 and 100 DAS, respectively. Almost all the plant and yield contributing characters showed significant variation except days to 6 leaf stage and days to bud initiation stage. The maximum yields were recorded in $\mathrm{V}_{1} \mathrm{l}_{3}\left(7.92 \mathrm{tha}^{-1}\right)$ which was statistically identical to $\mathrm{V}_{4} \mathrm{I}_{3}\left(7.83 \mathrm{tha}^{-1}\right), \mathrm{V}_{2} \mathrm{I}_{3}\left(7.45 \mathrm{tha}^{-1}\right), \mathrm{V}_{1} \mathrm{I}_{2}\left(7.40 \mathrm{tha}^{-1}\right), \mathrm{V}_{2} \mathrm{I}_{2}\left(6.87 \mathrm{t} \mathrm{ha}^{-1}\right)$ and $\mathrm{V}_{4} \mathrm{I}_{2}(6.80 \mathrm{t}$ $\left.\mathrm{ha}^{-1}\right)$, respectively. The highest benefit cost ratio (BCR) was observed (2.37) in both $\mathrm{V}_{1} \mathrm{I}_{3}$ and $\mathrm{V}_{1} \mathrm{I}_{2}$ treatment combination. Moreover, total average water saving in one hectare land for maize cultivation by adopting $I_{2}$ irrigation treatment over $I_{3}$ is $4,49,837$ gallons. Among the treatment combinations, $V_{1} I_{3}$ (BARI Hybrid Maize- 5 with three irrigations at 25, 50 and 75 DAS) was the suitable combination in terms of grain yield and economic return for maize cultivation.
\end{abstract}

\section{Introduction}

Maize (Zea mays L.) is considered as the third cereal crop in Bangladesh after rice and wheat. Its position is the first among the cereals in terms of yield, but area and production ranks third after rice and wheat. It covers about 4,09,000 acres of land producing 10,18,000 tons of grains in 2010-11 (BBS, 2011) in Bangladesh.

Hybrid maize cultivation area has increased at the rate of about $20-25 \%$ per year since nineties. Now-a-days, there are many government and non government organizations are working for increasing maize production in Bangladesh. Besides, Bangladesh Agricultural Research Institute (BARI) has released eleven promising hybrid maize varieties. Variety plays an important role in producing high yield and good quality maize. Different varieties respond differently to input supply, cultivation practices and prevailing environment etc. during the growing season. Higher yield up to 9-11 $\mathrm{t} \mathrm{ha}^{-1}$ can be obtained using hybrid seeds, balanced fertilizers and better management practices (Mondal et al., 2014). The average yield of maize in Bangladesh is rather low compared with leading maize growing countries of the world. Availability as well as the cost of management of irrigation water is one of the most expensive inputs for maize cultivation. Moreover, at present, the farmers are facing the problem of getting available irrigation water and may be acute in future because of the lowering water table day by day. Proper growth and development of maize needs 
Bhuiyan et al.

favorable soil moisture up to its root zone. Limited water supply during the growing season results in soil and plant water deficits and reduces maize yields (Gordon, et al., 1995; Patel et al., 2006). Irrigation scheduling is necessary for the most effective use of valuable water for optimizing maize production. Proper water management reduces irrigation cost. So,for proper growth and development of hybrid maize, appropriate irrigation scheduling is needed (Lafound et al., 1992; Arshad et al., 1995). Improper scheduling of irrigation results not only in wastage of water but decrease the crop growth and in yield.

In these circumstances, a research work was undertaken to find out the suitable maize hybrid variety (s) with lower water requirement and to find out the best irrigation management practices for higher economic return.

\section{Materials and Methods}

The study was conducted at the experimental farm of Sher-e-Bangla Agricultural University, Dhaka-1207, during December 2010 to May 2011. The location of the experimental site was situated at $23^{\circ} 77^{\prime} \mathrm{N}$ latitude and $90^{\circ} 3^{\prime} \mathrm{E}$ longitudes with an elevation of 8.6 meter from the sea level. The experimental site wassituated in the subtropical zone. The soil of the experimental site belongs to Madhupur Tract of Agro Ecological Zone (AEZ-28) (FAO, 1988). The soil was clay loam in texture and olive gray with common fine to medium distinct dark yellowish brown mottles. The $\mathrm{pH}$ was 5.47 to 5.63. The organic matter and $\mathrm{K}$ content of the soil is low but status of CEC and $P$ is medium (BARC, 2005). The experiment was set up in a split plot design with three replications where Variety $\left(V_{1}=B A R I\right.$ Hybrid Maize-5, $V_{2}=$ Pacific-60, $V_{3}=$ NK-40 and $V_{4}=$ Ajanta) in main plot and Irrigation level $\left(\mathrm{l}_{1}=\right.$ Two irrigations at 25 and 50 DAS, $I_{2}=$ Three irrigations at 25, 50 and 75 DAS and $I_{3}=$ Four irrigations at 25, 50,75 and 100 DAS, respectively) in sub-plot. Irrigation have been applied to reach the soil moisture upto field capacity so no infiltrations have been occurred. The dosages of fertilizer (512-275-200-222-14-6 kg/ha Urea-TSP-MoP-Gypsum-ZnSO ${ }_{4}$-Boric Acid) were applied according to FRG, 2005, BARC. Seeds were sown by hand at $75 \mathrm{~cm}$ apart line to line and 25 $\mathrm{cm}$ plant to plant. Post sowing light irrigation was given for proper germination of seeds.

Two weedings were done at 24 and 49 days after sowing (DAS) and two thinning were done also at 24 and 49 DAS, keeping one plant per hill. The mixture of Diazinon 60 EC @ $2 \mathrm{ml} / \mathrm{L}$ and Ripcord 10 EC @ $1 \mathrm{ml} / \mathrm{L}$ of water was applied to control leaf cutting caterpillar at 6-8 leaf stage for two times, seven days interval. The water requirement for maize cultivation is determined by measuring the soil moisture. The depth or water requirement can be determined by the following equation-

Irrigation depth,

$$
\mathrm{d}=\frac{\mathrm{FC}(\%)-\mathrm{MCi}(\%)}{100} \quad \mathrm{-} \quad \rho \quad \mathrm{X} \quad \mathrm{D}
$$

Where, $d=$ Depth of water to be applied $(\mathrm{cm}), \mathrm{FC}=$ Field capacity of the soil $(\%), \mathrm{MCi}=$ Moisture content of the soil at the time of irrigation (\%), $\rho$ = Bulk density of the soil ( $\mathrm{gm} / \mathrm{cc}), \mathrm{D}=$ Root zone depth $(\mathrm{cm})$

The collected data were statistically analyzed using MSTAT-C statistical programme with Least Significant Difference (LSD) by Gomez and Gomez (1984).

\section{Results and Discussion}

Interaction effects of variety and irrigation levels on plant characters of hybrid maize 
Performance of Hybrid Maize Varieties as Influenced by Irrigation Levels

Interaction effect of variety and irrigation levels varied significantly except days to 6 leaf stage and days to bud initiation stage (Table 1). All the combinations took 44-46 days to open the first 6 -leaf stage. The maximum days (82) were needed in $\mathrm{V}_{4} \mathrm{I}_{1}$ in 12 leaf stage and while other combination took almost similar days (76-77). The variation on days to bud initiation was insignificant while days to tassel emergence $t$ range maximum and minimum days (87 and 83). Days to tassel flowering were observed in different treatment combination from 86 to 89 days. Silk emerged just after the tassel flowering which also varied significantly, while The maximum days (90) in $\mathrm{V}_{2} \mathrm{I}_{3}, \mathrm{~V}_{3} \mathrm{l}_{1}$ and $\mathrm{V}_{3} \mathrm{I}_{3}$ and the minimum days (88). Days to pollen shedding were statistically significant where $V_{3} l_{3}$ needed the maximum day (92) while the minimum days (89) in $\mathrm{V}_{1} \mathrm{I}_{3}$. Nizam-uddin et al., (2010) and Malik et al., (2010) supported the above findings and stated that; cultivars differed significantly for all parameters.

\section{Interaction effects of variety and irrigation levels on yield and yield contributing characters of hybrid maize}

Interaction effect of different variety and irrigation levels treatment on yield and yield contributing characters of hybrid maize shown in Table 2. Plant height increases with increase the number of irrigation among all the varieties. Cob height showed almost the same trend of result found from the plant height. The nearest cob $(66 \mathrm{~cm})$ from the ground was found from $V_{3} l_{1}$ and the farthest cob $(97 \mathrm{~cm})$ in $V_{1} l_{3}$. The longest distance $(85 \mathrm{~cm})$ was found in $V_{1} I_{2}$ followed by $V_{4} I_{3}(83 \mathrm{~cm})$ and $V_{1} I_{3}(81 \mathrm{~cm})$ whereas the shortest in $V_{4} I_{1}(60 \mathrm{~cm})$ followed by $V_{3} l_{1}(61 \mathrm{~cm})$ and $V_{1} l_{1}(64 \mathrm{~cm})$. Number of cobs increased with the application of irrigation water. Among the variety, the maximum number of cobs (1.2) were found in $V_{2}$ and $V_{4}$ followed by $V_{1}(1.17)$ in $I_{3}$ irrigation treatment. The highest cob length $(16.7 \mathrm{~cm})$ was found from $V_{1} l_{3}$ while the lowest cob length $(13.3 \mathrm{~cm})$ from $V_{2} l_{1}$ and $V_{4} l_{1}$.

The grain weight per cob in the treatment combination $V_{4} I_{2}, V_{1} I_{2}$ and $V_{2} I_{2}$, were 142,141 and 139 , respectively followed by $V_{3} l_{3}(140 \mathrm{~g})$. 1000-grains weight increased with the number of application of irrigation water. However, the maximum 1000-grain weight was recorded in the treatment combination $V_{3} I_{3}$ which was statistically identical with $V_{3} I_{2} V_{4} I_{3} V_{4} I_{2}$ and $V_{1} l_{3}$. The grain yield of different treatment combination varied significantly where the highest grain yields was obtained in four irrigation $\left(I_{3}\right)$ and the lowest in two irrigation $\left(I_{1}\right)$ in all the variety. A gradual increasing trend was observed in every variety with the increase of irrigation level. Therefore, it is evident that, irrigation has a great effect on hybrid maize yield regardless of variety. Among the treatment combination, variety $V_{3}$ with all the irrigation levels gave the lowest yield, even its highest yield $\left(6.22 \mathrm{t} \mathrm{ha}^{-1}\right)$ in $\mathrm{I}_{3}$ was statistically at par with the $\mathrm{I}_{2}$ irrigation level of other varieties. The lowest yields $(4.89,5.01,5.53$ and $5.65 \mathrm{t}$ ha ${ }_{1}^{1}$, respectively) were recorded with $I_{1}$ irrigation level in $V_{3}, V_{4}, V_{1}$, and $V_{2}$, respectively. The yield increased in $V_{1}$ from $I_{1}$ to $I_{2}$ was $34 \%$ and $I_{2}$ to $I_{3} 7 \%$, in $V_{2}$ from $I_{1}$ to $I_{2}$ was $21 \%$ and $I_{2}$ to $I_{3} 8 \%$, in $V_{3}$ from $I_{1}$ to $I_{2}$ was $24 \%$ and $I_{2}$ to $I_{3} 2 \%$ and in $V_{4}$ from $I_{1}$ to $I_{2}$ was $35 \%$ and $I_{2}$ to $\mathrm{I}_{3} 15 \%$, respectively. It was also observed that, incase of $\mathrm{V}_{1}$ the yield in $\mathrm{I}_{2}$ was better than the yield of other varieties in $\mathrm{I}_{2}$ irrigation. Aziz et al., (2011) observed that, among the varieties BARI Hybrid Maize-5 produced maximum grain yield. Islam and Mian (2004) showed that, varieties had significant variation on yield and yield contributing characters. Biological yield of different treatment combination also varied significantly. The highest biological yield was obtained from $V_{1} l_{3}$ while lowest from $V_{1} l_{1}$.

Irrigation water utilization and economic analysis of different treatment combinations The average irrigation water used in $\mathrm{I}_{1}$ was 1209725 gallons $^{-1}{ }^{-1}$ with the average grain yield of $5.27 \mathrm{t} /$ ha whereas in $\mathrm{I}_{3}, 2079587$ gallons ha ${ }^{-1}$ with the grain yield of $7.36 \mathrm{t} \mathrm{ha}^{-1}$. In $\mathrm{I}_{2}$, moderate yield of $6.79 \mathrm{t} \mathrm{ha}^{-1}$ was observed with 1629750 gallons $^{-1} \mathrm{~h}^{-1}$ irrigation water which 
Bhuiyan et al.

was statistically identical to $I_{3}$. Moreover, 4, 49,837 gallons of water can be saved by using $I_{2}$ irrigation treatment without reducing significant quantity of grain yield. Among the varieties $V_{1}$ gave the highest yield $\left(7.40 \mathrm{tha}^{-1}\right)$ with $\mathrm{I}_{2}$ treatment Therefore, the treatment combination of $V_{1} I_{2}$ gave higher yield with moderate level of irrigation water (Table 3 ). In $I_{3}$ irrigation treatment higher amount water was used but yield was not statistically different from $\mathrm{I}_{2}$. Total average water saving in one hectare of land for maize cultivation by adopting $\mathrm{I}_{2}$ irrigation treatment over $I_{3}$ irrigation treatment was $(20,79,587-16,29,750)=4,49,837$ gallons. Therefore, $I_{2}$ irrigation treatment was optimum irrigation practices for maize cultivation considering yields and water saving aspect.

\section{Cost Benefit Analysis}

Effect of variety and irrigation combination on cost and economic benefit of the hybrid maize production has shown in Table 4. The highest total variable cost (Tk. 69028/ha) was observed in the $I_{3}$ treatment and the lowest total variable cost (Tk. 59028/ha) in $I_{1}$ treatment with all the varieties. The increment of cost (Tk. 4500/ha) and (Tk. 5500/ha) was found in $I_{2}$ from $I_{1}$ and $I_{3}$ from $I_{2}$, respectively. The highest human labor cost (Tk. 10500/ha) was found in $I_{3}$ irrigation treatment followed by $I_{2}$ (Tk. 10000/ha) and $I_{1}$ (Tk. 9500/ha), respectively. One time higher irrigation level increased the cost Tk. 1000 ha. The highest irrigation cost (Tk. $17000 / \mathrm{ha}$ ) was observed in the $I_{3}$ treatment whereas the lowest irrigation cost (Tk. 10000/ha) was observed in $I_{1}$ treatment. The highest gross return (Tk. 163870/ha) was found in $V_{1} I_{3}$ treatment combination which was similar to $\mathrm{V}_{4} \mathrm{I}_{3}$ (Tk.161115/ha) and the lowest gross return (Tk. 100710/ha) was in $V_{3} l_{1}$. The highest net return (Tk. 94842/ha) was found in $V_{1} I_{3} t$ which was followed by $V_{4} I_{3}$ (Tk. 92087/ha) treatment combination. The lowest net return was found in $V_{3} l_{1}$ (Tk. 41682/ha). The highest benefit cost ratio (BCR) 2.37 was observed in $V_{1} I_{2}$ and $\mathrm{V}_{1} \mathrm{I}_{3}$ treatment combination with three and four irrigations. The lowest BCR (1.71) was observed in $V_{3} l_{1}$ treatment combination followed by $V_{4} l_{1}$ (1.74) and $V_{1} l_{1}$ (1.90), respectively. Therefore, it was observed that $I_{2}$ irrigation treatment produced almost similar returns and benefit cost ratio with $I_{3}$ irrigation level. Moreover, a huge quantity of irrigation water can be saved by utilizing $I_{2}$ instead of $I_{3}$ irrigation level. So, $I_{2}$ irrigation treatment was the most effective treatment because yields and yield contributing characters of maize were very much similar with $I_{3}$ irrigation treatment. In $I_{1}$ irrigation treatment maize yields was lower with lower yield contributing characters.

Two, three and four irrigation increased yields by an additional 16.9, 6.7 and $4.3 \%$ respectively. Water savings can be achieved by applying two or three irrigations which should increase yield without significantly reducing yield compared to four irrigations. Pandey et al. (2000) observed that yield reduction (22.6-26.4\%) were found with deficit irrigation and this was associated with decrease in kernel number and weight. Karim et al., (2010) found that the coefficient of human labour, land preparation, irrigation, urea and borax have significantly impact on gross return.

Table 1. Interaction effect of variety and irrigation on different plant characters of hybrid maize

\begin{tabular}{l|c|c|c|c|c|c|c}
\hline $\begin{array}{l}\text { Treatment } \\
\text { Combination }\end{array}$ & $\begin{array}{c}\text { Days } \\
\text { to } \\
6 \text { leaf }\end{array}$ & $\begin{array}{c}\text { Days } \\
\text { to } \\
12 \text { leaf }\end{array}$ & $\begin{array}{c}\text { Days } \\
\text { to bud } \\
\text { initiation }\end{array}$ & $\begin{array}{c}\text { Days } \\
\text { to tassel } \\
\text { emergenc }\end{array}$ & $\begin{array}{c}\text { Days } \\
\text { to tassel } \\
\text { flowering }\end{array}$ & $\begin{array}{c}\text { Days } \\
\text { to silk } \\
\text { emergenc }\end{array}$ & $\begin{array}{c}\text { Days } \\
\text { to pollen } \\
\text { shedding }\end{array}$ \\
\hline
\end{tabular}


Performance of Hybrid Maize Varieties as Influenced by Irrigation Levels

\begin{tabular}{|c|c|c|c|c|c|c|c|}
\hline & & & & e & & e & \\
\hline $\mathrm{V}_{1} \mathrm{I}_{1}$ & 44 & 78 & 83 & 83 & 87 & 89 & 90 \\
\hline $\mathrm{V}_{1} \mathrm{I}_{2}$ & 45 & 76 & 82 & 85 & 88 & 89 & 90 \\
\hline $\mathrm{V}_{1} \mathrm{I}_{3}$ & 47 & 78 & 84 & 86 & 87 & 88 & 89 \\
\hline $\mathrm{V}_{2} \mathrm{I}_{1}$ & 44 & 77 & 82 & 84 & 87 & 89 & 90 \\
\hline $\mathrm{V}_{2} \mathrm{I}_{2}$ & 45 & 78 & 85 & 87 & 88 & 89 & 91 \\
\hline $\mathrm{V}_{2} \mathrm{I}_{3}$ & 46 & 76 & 82 & 86 & 88 & 90 & 90 \\
\hline $\mathrm{V}_{3} \mathrm{l}_{1}$ & 44 & 78 & 84 & 85 & 89 & 90 & 90 \\
\hline$V_{3} l_{2}$ & 46 & 79 & 84 & 86 & 87 & 89 & 90 \\
\hline $\mathrm{V}_{3} \mathrm{l}_{3}$ & 45 & 78 & 85 & 87 & 89 & 90 & 92 \\
\hline $\mathrm{V}_{4} \mathrm{I}_{1}$ & 45 & 82 & 83 & 83 & 87 & 89 & 90 \\
\hline $\mathrm{V}_{4} \mathrm{I}_{2}$ & 46 & 79 & 81 & 84 & 86 & 88 & 90 \\
\hline $\mathrm{V}_{4} \mathrm{l}_{3}$ & 47 & 77 & 82 & 85 & 87 & 89 & 90 \\
\hline LSD (0.05) & NS & 3.96 & NS & 2.78 & 2.11 & 1.97 & 1.46 \\
\hline CV (\%) & 2.70 & 3.00 & 2.57 & 1.93 & 1.43 & 1.30 & 0.96 \\
\hline
\end{tabular}

Table 2. Interaction effect of variety and irrigation on yield and yield contributing characters of hybrid maize

\begin{tabular}{l|c|c|c|c|c|c|c}
\hline $\begin{array}{l}\text { Treatment } \\
\text { Combination }\end{array}$ & $\begin{array}{c}\text { Plant } \\
\text { height } \\
(\mathrm{cm})\end{array}$ & $\begin{array}{c}\text { Cob } \\
\text { height } \\
(\mathrm{cm})\end{array}$ & $\begin{array}{c}\text { Cob } \\
\text { length } \\
(\mathrm{cm})\end{array}$ & $\begin{array}{c}\text { Grain } \\
\text { weight } \\
/ \\
\text { Cob }(\mathrm{g})\end{array}$ & $\begin{array}{c}1000- \\
\text { grain } \\
\text { weight } \\
(\mathrm{g})\end{array}$ & $\begin{array}{c}\text { Grain } \\
\text { yield } \\
(\mathrm{t} / \mathrm{ha})\end{array}$ & $\begin{array}{c}\text { Blologica } \\
\text { I yield } \\
(\mathrm{t} / \mathrm{ha})\end{array}$ \\
\hline $\mathrm{V}_{1} \mathrm{I}_{1}$ & 142 & 77 & 13.7 & 116 & 268 & 5.53 & 9.02 \\
$\mathrm{~V}_{1} \mathrm{I}_{2}$ & 170 & 84 & 15.0 & 131 & 290 & 6.60 & 12.14 \\
$\mathrm{~V}_{1} \mathrm{I}_{3}$ & 178 & 97 & 16.7 & 156 & 318 & 8.44 & 18.86 \\
$\mathrm{~V}_{2} \mathrm{I}_{1}$ & 149 & 81 & 13.3 & 119 & 297 & 5.95 & 10.00 \\
$\mathrm{~V}_{2} \mathrm{I}_{2}$ & 163 & 89 & 13.7 & 139 & 303 & 6.87 & 11.23 \\
$\mathrm{~V}_{2} \mathrm{I}_{3}$ & 170 & 92 & 15.3 & 145 & 309 & 7.94 & 15.22 \\
$\mathrm{~V}_{3} \mathrm{I}_{1}$ & 127 & 66 & 13.7 & 103 & 284 & 4.89 & 10.71 \\
$\mathrm{~V}_{3} \mathrm{I}_{2}$ & 156 & 80 & 15.0 & 127 & 339 & 6.11 & 13.20 \\
$\mathrm{~V}_{3} \mathrm{I}_{3}$ & 163 & 91 & 15.3 & 140 & 340 & 6.63 & 16.53 \\
$\mathrm{~V}_{4} \mathrm{I}_{1}$ & 141 & 82 & 13.3 & 102 & 270 & 5.01 & 10.98 \\
$\mathrm{~V}_{4} \mathrm{I}_{2}$ & 159 & 91 & 14.7 & 142 & 319 & 6.8 & 13.99 \\
$\mathrm{~V}_{4} \mathrm{I}_{3}$ & 179 & 96 & 15.7 & 150 & 335 & 8.35 & 16.86 \\
\hline $\mathrm{LSD}(0.05)$ & 10.3 & 7.43 & 0.60 & 10.8 & 19.9 & 0.74 & 1.72 \\
$\mathrm{CV}(\%)$ & 7.76 & 10.3 & 4.83 & 9.76 & 7.69 & 13.40 & 15.30 \\
\hline
\end{tabular}

$\mathrm{V}_{1}=$ BARI Hybrid Maize $-5, \mathrm{~V}_{2}=$ Pacific $-60, \mathrm{~V}_{3}=\mathrm{NK}-40$ and $\mathrm{V}_{4}=$ Ajanta

$\mathrm{I}_{1}=$ Two irrigations at 25 and 50 DAS, $\mathrm{I}_{2}=$ Three irrigations at 25,50 and 75 DAS and $\mathrm{I}_{3}=$ Four irrigations at 25, 50, 75 and 100 DAS

Table 3. Total average irrigation water applied in different treatment combination maize yield

\begin{tabular}{l|c|c|c}
\hline $\begin{array}{c}\text { Treatment } \\
\text { combination }\end{array}$ & $\begin{array}{c}\text { Total average water used } \\
(\mathrm{cm})\end{array}$ & $\begin{array}{c}\text { Total irrigation water used } \\
\text { (gallons/ha) }\end{array}$ & $\begin{array}{c}\text { Grain yield } \\
(\mathrm{t} / \mathrm{ha})\end{array}$ \\
\hline
\end{tabular}


Bhuiyan et al.

\begin{tabular}{llll}
\hline$I_{1} V_{1}$ & 45.8 & 1213700 & 5.53 \\
$I_{1} V_{2}$ & 46.3 & 1226950 & 5.65 \\
$I_{1} V_{3}$ & 46.3 & 1226950 & 4.89 \\
$I_{1} V_{4}$ & 1171300 & 5.01 \\
$I_{2} V_{1}$ & 16.2 & 1629750 & 7.40 \\
$I_{2} V_{2}$ & 61.5 & 1627100 & 6.87 \\
$I_{2} V_{3}$ & 61.4 & 1658900 & 6.11 \\
$I_{2} V_{4}$ & 62.6 & 1603250 & 6.80 \\
$I_{3} V_{1}$ & 60.5 & 2143850 & 7.92 \\
$I_{3} V_{2}$ & 80.9 & 2090850 & 7.45 \\
$I_{3} V_{3}$ & 78.4 & 2032550 & 6.22 \\
$I_{3} V_{4}$ & 76.7 & 2051100 & 7.83 \\
\hline
\end{tabular}

$V_{1}=$ BARI Hybrid Maize $-5, V_{2}=$ Pacific $-60, V_{3}=$ NK -40 and $V_{4}=$ Ajanta

$\mathrm{I}_{1}=$ Two irrigations at 25 and 50 DAS, $\mathrm{I}_{2}=$ Three irrigations at 25, 50 and 75 DAS and $\mathrm{I}_{3}=$ Four irrigations at $25,50,75$ and 100 DAS

Table 4. Effect of variety and irrigation on cost and economic benefit

\begin{tabular}{|c|c|c|c|c|c|c|c|c|c|c|c|c|}
\hline \multirow{2}{*}{$\begin{array}{l}\text { Cost } \\
\text { items }\end{array}$} & \multicolumn{12}{|c|}{ Treatment combination } \\
\hline & $\mathrm{V}_{1} \mathrm{I}_{1}$ & $\mathrm{~V}_{1} \mathrm{I}_{2}$ & $\mathrm{~V}_{1} \mathrm{I}_{3}$ & $\mathrm{~V}_{2} \mathrm{I}_{1}$ & $\mathrm{~V}_{2} \mathrm{l}_{2}$ & $\mathrm{~V}_{2} \mathrm{I}_{3}$ & $\mathrm{~V}_{3} \mathrm{I}_{1}$ & $\mathrm{~V}_{3} \mathrm{I}_{2}$ & $\mathrm{~V}_{3} \mathrm{I}_{3}$ & $\mathrm{~V}_{4} \mathrm{I}_{1}$ & $\mathrm{~V}_{4} \mathrm{I}_{2}$ & $\mathrm{~V}_{4} \mathrm{I}_{3}$ \\
\hline $\begin{array}{l}\text { H. } \\
\text { Labors } \\
\text { (Tk./ha)* }\end{array}$ & 9500 & 10000 & 10500 & 9500 & 10000 & 10500 & 9500 & 10000 & 10500 & 9500 & 10000 & 10500 \\
\hline $\begin{array}{l}\text { Fuel } \\
\text { (Tk./ha) }\end{array}$ & 3000 & 4000 & 5000 & 3000 & 4000 & 5000 & 3000 & 4000 & 5000 & 3000 & 4000 & 5000 \\
\hline $\begin{array}{l}\text { Manure } \\
\text { (Tk./ha) }\end{array}$ & 10000 & 10000 & 10000 & 10000 & 10000 & 10000 & 10000 & 10000 & 10000 & 10000 & 10000 & 10000 \\
\hline $\begin{array}{l}\text { Urea } \\
\text { (Tk./ha) }\end{array}$ & 2000 & 2000 & 2000 & 2000 & 2000 & 2000 & 2000 & 2000 & 2000 & 2000 & 2000 & 2000 \\
\hline $\begin{array}{l}\text { TSP } \\
\text { (Tk./ha) }\end{array}$ & 9612 & 9612 & 9612 & 9612 & 9612 & 9612 & 9612 & 9612 & 9612 & 9612 & 9612 & 9612 \\
\hline $\begin{array}{l}\text { MP } \\
\text { (Tk./ha) }\end{array}$ & 10656 & 10656 & 10656 & 10656 & 10656 & 10656 & 10656 & 10656 & 10656 & 10656 & 10656 & 10656 \\
\hline $\begin{array}{l}\text { Gypsum } \\
\text { (Tk./ha) }\end{array}$ & 660 & 660 & 660 & 660 & 660 & 660 & 660 & 660 & 660 & 660 & 660 & 660 \\
\hline $\begin{array}{l}\text { Boric acid } \\
\text { (Tk./ha) }\end{array}$ & 600 & 600 & 600 & 600 & 600 & 600 & 600 & 600 & 600 & 600 & 600 & 600 \\
\hline $\begin{array}{l}\text { Irrigation } \\
\text { (Tk./ha) }\end{array}$ & 10000 & 13000 & 17000 & 10000 & 13000 & 17000 & 10000 & 13000 & 17000 & 10000 & 13000 & 17000 \\
\hline $\begin{array}{l}\text { Seeds } \\
\text { (Tk./ha) }\end{array}$ & 3000 & 3000 & 3000 & 3000 & 3000 & 3000 & 3000 & 3000 & 3000 & 3000 & 3000 & 3000 \\
\hline $\begin{array}{l}\text { TVC } \\
\text { (Tk./ha)\# }\end{array}$ & 59028 & 63528 & 69028 & 59028 & 63528 & 69028 & 59028 & 63528 & 69028 & 59028 & 63528 & 69028 \\
\hline $\begin{array}{l}\text { Gross } \\
\text { return } \\
\text { (Tk./ha) }\end{array}$ & 112345 & 150370 & 163870 & 115175 & 139580 & 152885 & 100710 & 125690 & 129555 & 103185 & 139595 & 161115 \\
\hline $\begin{array}{l}\text { Net } \\
\text { return } \\
\text { (Tk./ha) }\end{array}$ & 53317 & 86842 & 94842 & 56147 & 76052 & 83857 & 41682 & 62162 & 60527 & 44154 & 76067 & 92087 \\
\hline $\begin{array}{l}\text { Benefit } \\
\text { cost ratio }\end{array}$ & 1.90 & 2.37 & 2.37 & 1.95 & 2.19 & 2.21 & 1.71 & 1.98 & 1.88 & 1.74 & 2.19 & 2.33 \\
\hline
\end{tabular}

a) Maize $=20.00 \mathrm{Tk} . / \mathrm{kg} \quad$ b) Labor $=250 \mathrm{Tk} . / \mathrm{day}{ }^{*} \mathrm{H}$. Labors= Human Labors, \#TVC=Total Variable Cost

\section{Conclusion}

From the above findings, it may be concluded that, all the selected hybrid maize varieties viz., BARI Hybrid Maize-5, Pacific-60 and Ajanta except NK-40 gave higher benefits in three irrigation levels at 25,50 and 75 days after seeding (DAS). But it may be noted that, maize 
Performance of Hybrid Maize Varieties as Influenced by Irrigation Levels

variety (BARI Hybrid Maize- 5 with three irrigation levels at 25, 50 and 75 DAS was the best in terms of grain yield and return among all the treatment combination.

\section{References}

Arshad, M. A., Gill, K. S. and S. Coy. 1995. Barley, Canola, and weed growth with decreasing tillage in a cold, semiarid climate. Agron. J. 87: 4-55.

Aziz, M. A., A. K. M. M. Rahman, R. Chakma, M. Ahmed and A. F. M. S. Ahsan. 2011. Performance of BARI hybrid maize varieties in the hilly areas of Bangladesh. J. Expt. Biosci. 2(2): 25-28.

BARC (Bangladesh Agricultural Research Council). 2005. Fertilizer Recommendation Guide, 2005. Bangladesh Agril. Res. Council, Farmgate, New Airport Road, Dhaka. p. 15.

BBS (Bangladesh Bureau of Statistics). 2011. Statistcal Yearbook of Bangladesh, Statistics Division, Ministry of Planning, Govt. Peoples Repub. Bangladesh. p. 207.

Gomez, K. A. and A. A. Gomez. 1984. Statistical procedures for agricultural research. A Wiley Int. Sci. Publ. John Wiley and Sons. New York, Brisbane, Singapore. pp. 139-240.

Gordon, W. B., R. J. Raney and L. R. Stone. 1995. Irrigation management practice for corn production in north central Kansas. J. Soil Water Conserve. 50(4): 395-398.

Islam, A. K. M. A. and M. A. K. Mian. 2004. Comparative performance of ten hybrid Maize (Zea mays L.). Bangladesh J. Plant. Breed. Genet. 17(2): 09-14.

Karim, M. R., M. Moniruzzaman and Q. M. Alam. (2010). Economics of hybrid maize production in some selected areas of Bangladesh. Bangladesh J. Agril. Res. 35(1): 83-93.

Lafoud, G. P., H. Loeppky and D. A. Derksen. 1992. The effect of tillage systems and crop rotations on soil water conservation, seedling establishment and crop yield. Can. J. Plant Sci. 72: 103-115.

Malik, H. N, I. Ara, M. Naeem, M. Hussain, M. H. Munawwar and M. Yousaf. 2010. Comparison of open pollinated varieties and newly developed hybrids for yield and yield contributing traits in maize. Pakistan J. Agril. Res. 23(1/2): 37-41.

Mondal, M. R. I., M. K. Sultan, S. Nur, M. J. U. Sarkar, M. S. Alam and M. H. H. Rahman. 2014. KRISHI PROJUKTI HATBOI (Handbook on Agro-technology), 6 th edition. Bangladesh Agricultural Research Institute, Gazipur 1701, Bangladesh.

Nizamuddin, M. Qasimand M. Hussain. 2010. Comparative study of agronomic parameters in synthetic maize varieties. J. Agril. Res., Lahore. 48(1): 53-57.

Patel, J. B., V. J. Patel and J. R. Patel. 2006. Influence of different methods of irrigation and nitrogen levels on crop growth rate and yield of maize (Zea mays L.). Ind. J. Crop Sci., 1(1-2): 175-177. 